\title{
PROTEIN ADHESI SUB UNIT PILI Shigella flexneri 18 kDa MENINGKATKAN EKSPRESI PROTEIN ANTIMIKROBA $\beta$ DEFENSIN PADA MENCIT ( STRATEGI PENGEMBANGAN VAKSIN SHIGELLOSIS BERBASIS PROTEIN
} ADHESI)

\section{ADHESION PROTEIN PILI SUB UNIT 18 kDa Shigella flexneri IMPROVES EXPRESSION MICE DEFENSIN ANTIMICROBIAL PROTEIN (SHIGELLOSIS VACCINES DEVELOPMENT STRATEGY BASED ON PROTEIN ADHESION)}

\author{
Avin Ainur Fitrianingsih ${ }^{1}$, Lailia Nur Rachma ${ }^{1}$, Alvi Milliana ${ }^{1}$ \\ ${ }^{1}$ School of Medicine, Faculty of Medical and Health Sciences, Universitas Islam Negeri \\ Maulana Malik Ibrahim, Malang Indonesia \\ avinainur@kedokteran.uin-malang.ac.id
}

\begin{abstract}
ABSTRAK
Shigellosis merupakan penyakit endemis yang terutama terjadi di negara berkembang dan merupakan penyebab tersering penyakit diare yang berdarah. Pengembangan vaksin dari molekul adhesin memiliki kelebihan pada reaksi imun tubuh yang terbentuk akan membentuk sistem pertahanan tubuh yang lebih kuat dalam mengeliminasi bakteri serta tidak menimbulkan panas seperti vaksin dari sel utuh bakteri atau dari LPSnya. Berdasarkan penelitian sebelumnya diketahui bahwa pili Shigella flexneri dengan Berat Molekul (BM) 18 $\mathrm{kDa}$ merupakan molekul adhesi serta mampu bereaksi silang dengan pili Shigella spesies lainnya. Penelitian ini dimulai dengan proses isolasi pili $S$. flexneri, kemudian dilanjutkan dengan profiling pili dengan cara elektroforesis SDS-PAGE. Kemudian dilakukan perbanyakan protein sub unit pili dengan elektroelusi. Protein sub unit yang sudah diperoleh kemudian diimunisasikan ke mencit Balb/c secara peroral menggunakan sonde, dengan pemberian 4 kali selang 1 minggu, dan pada akhir minggu ke 4 mencit dimatikan. Serum, mukosa usus dan paru mencit yang didapatkan kemudian diuji kadar Antimicrobial peptide $\beta$ defensin dengan metode ELISA. Kesimpulan penelitian ini adalah pemberian protein adhesi sub unit pili $S$. flexneri 18 kDa selama 4 minggu mampu meningkatkan kadar Antimicrobial peptide $\beta$ defensin pada serum, mukosa usus, dan paru mencit. Sehingga protein adhesi sub unit pili S. flexneri $18 \mathrm{kDa}$ berpotensi menjadi vaksin berbasis sub unit protein adhesi untuk kasus Shigellosis.
\end{abstract}

Kata Kunci : Shigella flexneri, sub unit pili $18 \mathrm{kDa}$, Antimicrobial peptide $\beta$ defensin

\begin{abstract}
Shigellosis is an endemic disease that mainly occurs in developing countries and is the most common cause of bloody diarrhea. Vaccine development from adhesin molecules has advantages in the body's immune reactions that are formed which will form a stronger body's defense system in eliminating bacteria and not causing heat such as vaccines from intact bacterial cells or from its LPS. Based on previous research, it is known that Shigella flexneri pili with Molecular Weight (BM) $18 \mathrm{kDa}$ is an adhesion molecule and is able to cross-react with other species of Shigella pili. This study began with the isolation process of S. flexneri pili, followed by profiling pili by SDS-PAGE electrophoresis. Then the protein multiplication of pili sub-units was carried out by electroelution. The sub unit protein that has been obtained is then immunized into Balb / c mice orally using sonde, with 4 times a week, and at the end of the fourth week the mice are sacrificed. Serum, intestinal and lung mucosa obtained from mice were then tested for Antimicrobial peptide $\beta$ defensin levels using ELISA method. The conclusion of this study is the administration of adhesion protein sub-unit pili $18 \mathrm{kDa}$ $S$. flexneri for 4 weeks can increase levels of antimicrobial peptide $\beta$ defensin in serum, intestinal mucosa, and
\end{abstract}


lung of mice. So that the adhesion protein of the sub unit pili $18 \mathrm{kDa}$ S. flexneri has the potential to become a vaccine based sub-protein adhesion unit for the case of Shigellosis.

Keywords: Shigella flexneri, pili $18 \mathrm{kDa}$ sub unit, Antimicrobial peptide $\beta$ defensin

\section{PENDAHULUAN}

Shigellosis merupakan masalah kesehatan bagi seluruh penduduk dunia. Di Indonesia, diare merupakan salah satu penyebab utama kematian bayi. ${ }^{1}$ Berdasarkan hasil survei pada balita di beberapa rumah sakit di Indonesia dan studi yang dilakukan di Jakarta Selatan pada 612 anak umur 0-12 tahun, Shigella flexneri terbukti sebagai etiologi utama diare. ${ }^{2,3}$

Patogenesis diare oleh S. flexneri merupakan mekanisme yang komplek yang menyebabkan proses inflamasi usus berat dan nekrosis epitelium kolon. Kemampuan Shigella melintasi mukosa kolon, berkolonisasi di epitelium usus, dan mendownregulasi antimicrobial peptide yang merupakan antibiotik alami tubuh adalah kunci penyebab sangat virulen-nya bakteri ini, ${ }^{4,5}$ sehingga konsumsi $10-100$ bakteri dapat menyebabkan individu menderita diare berat. ${ }^{6}$

Dikarenakan berbagai kemampuan yang dimiliki S. flexneri untuk menghindar dari mekanisme kerja antibiotik, saat ini telah banyak dilaporkan resistensi antibiotic multidrug oleh $S$. flexneri sehingga dapat meningkatkan risiko epidemi di berbagai negara termasuk Indonesia. Oleh karena itu World Health Organization memprioritaskan pengembangan vaksin yang efektif dan aman untuk membantu pengendalian Shigellosis. ${ }^{7}$

Tujuan dari penelitian ini membuktikan pengaruh protein adhesi sub unit pili S. flexneri $18 \mathrm{kDa}$ sebagai kandidat vaksin terhadap level protein antimikroba $\beta$ defensin.

Metode yang digunakan adalah dengan memberikan imunisasi menggunakan molekul adhesi S. flexneri $18 \mathrm{kDa}$ secara peroral pada hewan coba mencit balb/c. Kemudian ditinjau daya protektivitas dan respon imun berupa level protein $\beta$ defensins yang diisolasi dari mucus lumen usus mencit, darah, dan paru. $\beta$ defensins dianalisa menggunakan metode ELISA. Hasil penelitian ini diharapkan dapat menunjang ditemukannya vaksin yang handal untuk mengatasi shigellosis.

\section{BAHAN DAN METODE PENELITIAN}

\section{Bahan penelitian}

Bahan yang digunakan dalam penelitian ini adalah : bakteri $S$. flexneri diperoleh dari Laboratorium Kesehatan DI Yogyakarta; Medium pembiakan bakteri: medium Mc.Conkey, medium Thiaproline Carbonate Glutamate (TCG) agar, Bismuth sulfite agar (BSA) dan Brain Heart Infusion (BHI) broth; Hewan coba: mencit galur Balb/C jantan usia 6-8 minggu dengan berat badan \pm 25 gram; Reagen Kimia: TCA (Trichloroacetic acid), ammonium sulfat, NaCitrat, EDTA (Ethylene diamine tetra-acetatic acid), EGTA (Ethylene glycol tetra-acetic acid), dithitreitol, $\mathrm{NaCL}, \mathrm{Na}_{2} \mathrm{HPO}_{4}, \mathrm{KH}_{2} \mathrm{PO}_{4}$, ethanol, acrylamid, bis acrylamid, glisin, trisHCL, tris base, SDS, temed, ammonium persulfat, commassie blue, methanol, asam asetat 
glacial, gliserol, brompenol, brompenol blue, Tween 20; Protease inhibitor: protease inhibitor cocktail (Sigma Ultra); Adjuvant: CTB; Mouse beta defensin ELISA kit.

\section{Alat penelitian}

Alat yang digunakan dalam penelitian ini adalah : Lempeng mikrotiter bentuk $U$ dan bentuk $\mathrm{V}$, membrane dialysis, membrane elektroelusi, tips, tabung sentrifus $1,5 \mathrm{ml}$ (eppendorf), $15 \mathrm{ml}$, pipet mikro 5 - $20 \mu \mathrm{l}, 50$ - $200 \mu \mathrm{l}, 200$ - $1000 \mu \mathrm{l}$, jarum suntik; Alat-alat gelas; Omni-mixer modifikasi, magnetic stirrer, incubator, otoklaf, ELISA reader, pili cutter (Desain Sumarno), mikroskop.

\section{METODE PENELITIAN}

\section{Persiapan Bakteri S. flexneri.}

Isolat S. flexneri dikultur pada medium SSA (Salmonella Shigella Agar) pada suhu $37^{\circ} \mathrm{C}$ selama 24 jam untuk memastikan kemurnian sampel bakteri. S. flexneri yang dipanen dari kultur SSA secara terpisah kemudian dipindahkan ke cawan petri yang berisi medium MacConkey pada suhu $37{ }^{\circ} \mathrm{C}$ selama 24 jam untuk multiplikasi bakteri. Hasil kultur bakteri dari medium MacConkey kemudian dilarutkan dalam PBS $10 \mathrm{ml}$ dengan pH 7,4. Selanjutnya dimasukkan ke dalam botol berisi larutan BHI (Brain Heart Infusion) $1000 \mathrm{ml}$. Botol tersebut kemudian digoyang-goyang pada water bath selama 30 menit pada suhu 37 ${ }^{\circ} \mathrm{C}$. Kemudian setelah digoyang, isi medium BHI diambil sebanyak $10 \mathrm{~mL}$ dimasukkan ke dalam medium TCG yang telah dibuat sebelumnya. Inkubasi pada medium TCG dilakukan pada suhu $37{ }^{0} \mathrm{C}$ selama $2 \times 24$ jam.

\section{Isolasi Protein Pili S. flexneri.}

Koleksi protein pili S. flexneri mengacu pada metode yang dilakukan oleh Ehara ${ }^{8}$ dengan modifikasi Sumarno. Hasil koleksi bakteri dikumpulkan dalam satu botol steril yang kemudian ditambahkan Tricoleracetic Acid (TCA) dengan konsentrasinya 3\%. Selanjutnya dilakukan sentrifugasi dengan kecepatan sebesar $6.000 \mathrm{rpm}$ selama 30 menit pada suhu $4{ }^{\circ} \mathrm{C}$. Endapan yang terbentuk merupakan whole-cell dari S. flexneri sedangkan supernatannya adalah produk metabolit dari bakteri tersebut. Endapan hasil sentrifugasi kemudian diencerkan memakai cairan PBS pH 7,4 dengan perbandingan endapan : pengencer $=1: 10$ sehingga terbentuk suspensi baru. Suspensi bakteri kemudian dilakukan pemotongan pili dengan kecepatan $5.000 \mathrm{rpm}$ selama 30 detik pada suhu $4^{\circ} \mathrm{C}$. Setelah itu hasil pemotongan dimasukkan kedalam tabung falcon dan disentrifugasi dengan kecepatan 12000 rpm selama 30 menit. Hasil supernatan merupakan pili, sedang endapannya diencerkan dengan PBS PH 7,4 dengan perbandingan endapan : PBS $=1$ : 1 . Setelah diencerkan maka hasil pengenceran endapan dapat disimpan atau dapat dilakukan langsung dilakukan persiapan karakterisasi pili menggunakan metode elektroforesis.

\section{Sodium Dodecyl Sulfate - Polyacrilamide Gel Electrophoresis (SDS-PAGE).}


Monitoring berat molekul molekul dikerjakan dengan SDS-PAGE metode Laemli, (1970). Sample protein dipanaskan $100^{\circ} \mathrm{C}$ selama 5 menit dalam larutan penyangga yang mengandung $5 \mathrm{mM}$ Tris $\mathrm{pH}$ 6,8; $5 \%$ 2-mercapto ethanol; 2,5\% w/v sodium dodecyl sulfate, $10 \% \mathrm{v} / \mathrm{v}$ glycerol dengan menggunakan warna pelacak bromophenol blue. Dipilih 12,5 mini slab gel dengan tracking gel 4\%. Voltase aliran listrik yang digunakan adalah $120 \mathrm{mV}$. Sebagai bahan warna yang digunakan adalah comassie brilliant blue dan molekul standar sigma low range marker. Setelah dilakukan perhitungan berat molekul maka dilakukan perbanyakan protein dengan berat molekul $18 \mathrm{kDa}$ dan molekul kemudian dilakukan permurnian protein yaitu elektroelusi

\section{Pemberian Imunisasi}

Imunisasi diberikan peroral pada mencit dengan menggunakan sonde. Imunisasi diberikan 4 kali selang 1 minggu, dan pada akhir minggu ke 4 mencit dikorbankan, dan diambil usus, paru dan serumnya.

\section{Preparasi Sampel homogenates usus dan omentum mencit}

Dilakukan pengorbanan mencit dengan dislokasi leher, kemudian mencit di tempatkan pada suatu tatakan gabus yang dilapisi alumunium foil, difiksasi pada keempat ekstremitas. Bagian perut mencit dibuka dengan gunting sampai terlihat organ dalam abdomen. Darah diambil dengan spuit $1 \mathrm{cc}$ dari jantung mencit. Kemudian usus paru dihomogenisasikan dengan $1 \mathrm{ml}$ PBS dan kemudian didisimpan pada suhu $-20^{\circ} \mathrm{C}$ overnight. Setelah dua kali siklus freeze-thaw untuk menghancurkan membran sel, homogentaes disentrifugasi $5000 \mathrm{x} \mathrm{g}$ selama 5 menit pada suhu $2-8^{0} \mathrm{C}$. Supernatan diambil dilakukan pemurnian, disuspensi dengan PBS dan dilakukan dialisis menggunakan PBS dan digunakan sebagai sampel untuk pemeriksaan kadar defensin dengan metode ELISA.

\section{HASIL DAN PEMBAHASAN \\ Hasil Isolasi pili Shigella flexneri}

Penggunaan protein adhesi pili S. flexneri dengan berat $18 \mathrm{kDa}$ adalah berdasarkan penelitian yang dilakukan pada tahun 2016 yang dapat membuktikan bahwa molekul tersebut merupakan molekul adhesin. Hasil dari isolasi protein adhesi pili $S$. flexneri $18 \mathrm{kDa}$ dapat dilihat pada gambar berikut. 


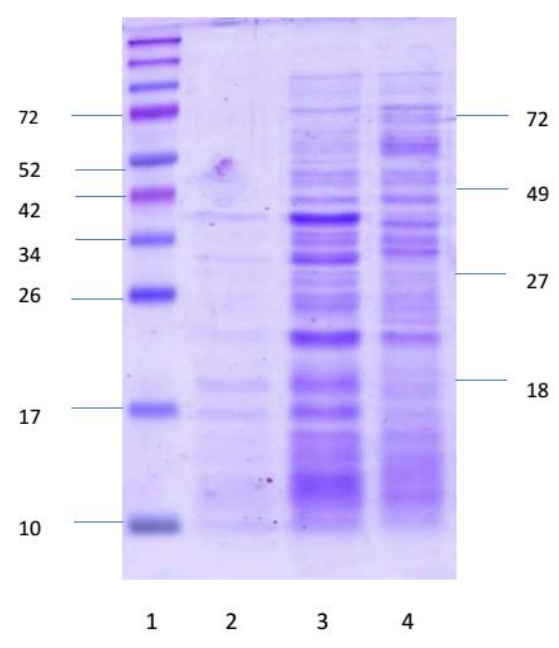

Gambar: Hasil elektroforesis SDS-PAGE 12,5\% pili S. flexneri

Keterangan:

1. marker

2. potongan pili $1 S$. flexneri

3. potongan pili $2 S$. flexneri

4. Potongan pili $3 S$. flexneri

Tabel Hasil Pengukuran Kadar $\beta$ Defensin

\begin{tabular}{|c|c|c|c|c|c|c|}
\hline \multirow[b]{2}{*}{ Sampel } & \multicolumn{6}{|c|}{$\begin{array}{c}\text { Kadar } \beta \text { Defensin } \\
(\mathrm{pg} / \mathrm{mL})\end{array}$} \\
\hline & $\begin{array}{l}\text { Serum } \\
\text { kelompok } \\
\text { kontrol }\end{array}$ & $\begin{array}{l}\text { Serum } \\
\text { kelompok } \\
\text { imunisasi } \\
\text { sub unit pili } \\
18 \text { kDa }\end{array}$ & $\begin{array}{l}\text { paru } \\
\text { kelompok } \\
\text { kontrol }\end{array}$ & $\begin{array}{l}\text { Paru } \\
\text { kelompok } \\
\text { imunisasi } \\
\text { sub unit pili } \\
18 \text { kDa }\end{array}$ & $\begin{array}{l}\text { Usus } \\
\text { kelompok } \\
\text { kontrol }\end{array}$ & $\begin{array}{l}\text { usus } \\
\text { kelompok } \\
\text { imunisasi } \\
\text { sub unit pili } \\
18 \text { kDa }\end{array}$ \\
\hline 1 & 25,989 & 36,813 & 17,039 & 23,681 & 58,862 & 279,102 \\
\hline 2 & 23,681 & 36,813 & 17,039 & 23,269 & 59,194 & 303,347 \\
\hline 3 & 24,888 & 37,933 & 18,126 & 23,515 & 58,862 & 258,321 \\
\hline 4 & 24,188 & 37,933 & 17,890 & 24,622 & 64,575 & 339,996 \\
\hline 5 & 23,765 & 38,263 & 17,094 & 22,089 & 59,529 & 324,359 \\
\hline 6 & 23,681 & 36,813 & 17,039 & 23,598 & 64,575 & 357,158 \\
\hline 7 & 24,888 & 39,801 & 18,125 & 23,187 & 58,862 & 249,006 \\
\hline 8 & 24,188 & 37,933 & 17,890 & 23,107 & 64,575 & 253,582 \\
\hline 9 & 23,681 & 38,263 & 18,185 & 22,241 & 64,191 & 310,053 \\
\hline $\begin{array}{l}\text { Rata- } \\
\text { rata }\end{array}$ & 24,328 & 37,840 & 17,603 & 23,257 & 61,469 & 297,214 \\
\hline
\end{tabular}

Kemudian setelah dilakukan analisis statistik didapatkan hasil bahwa terdapat perbedaan yang signifikan kadar defensin mencit baik dari sampel serum, mukosa usus, maupun paru apabila dibanding dengan kelompok kontrol (tanpa perlakuan). Sedangkan kadar defensin pada usus mencit didapatkan hasil paling tinggi bila dibanding dengan kadar defensin pada serum dan paru mencit.

PEMBAHASAN 
Sub unit yang diujikan pada penelitian ini adalah sub unit protein pili S. flexneri 18 $\mathrm{kDa}$ yang telah dipotong dari permukaan luar bakteri. Protein yang diberikan tersebut merupakan molekul adhesi yang merupakan sub unit bakteri yang memiliki efek samping reaksi lokal dan reaksi sistemik yang lebih ringan dibanding pemberian whole cell yang dilemahkan. ${ }^{9}$ Beberapa penelitian menggunakan murine sebagai hewan coba menunjukkan fakta bahwa vaksinasi subunit dapat menginduksi sel Th1 secara kuat dengan long term memory dan daya tahan yang sama atau melebihi tingkat perlindungan yang dicapai menggunakan wild type microorganism..$^{10,11,12}$

Pemilihan Mice beta defensin-14 (MBD-14) dikarenakan MBD-14 telah diidentifikasi sebagai orthologue beta-defensin 3 manusia (hBD3 atau DEFB103). Selain memiliki kesamaan struktur sekitar $70 \%$, MBD-14 memiliki karakteristik fungsional yang serupa dengan HBD-3. Sama dengan HBD3, MBD-14 memiliki peran yang sangat penting pada respon antimikroba pada sistem imun innate. ${ }^{13}$ MBD-14 juga memiliki kemampuan untuk menginduksi respon inflamasi lokal bawaan dan respon kekebalan adaptif sistemik dengan berinteraksi dengan CCR6 reseptor. MBD14 juga didapatkan pada berbagai jaringan termasuk limpa, usus, dan saluran pernapasan atas dan bawah. Ekspresi MBD14 juga dapat diinduksi oleh ikatan dengan agonis reseptor Toll-like seperti lipopolisakarida dan oleh rangsangan sitokin pro-inflamasi seperti tumor necrosis faktor dan interferon-gamma. HBD3 dan mBD14 juga sama-sama memiliki kemampuan kemotaktik terhadap sel-sel kekebalan yang homing di area peritoneal. Sehingga, berdasarkan kesamaan struktural dan fungsional tersebut, MBD-14 merupakan orthologue dari hBD3 dan dapat digunakan dalam penelitian mewakili HBD-3 pada manusia. ${ }^{13}$

Selain struktur dan fungsi, MBD-14 memiliki keterkaitan dengan sitokin IL-17 dan IL-22 yang diujikan pada penelitian ini. Kehadiran pathogen pada mukosa usus yang telah ditangkap oleh APC yang kemudian dipresentasikan kepada sel Th 0 menyebabkan differensiasi Th 0 menjadi Th 17 yang memproduksi IL-17 dan IL-22. ${ }^{14}$ IL-17 dan IL-22 kemudian akan memacu sel epitel mukosa usus untuk memproduksi beta defensin. IL-17 ternyata tidak hanya dihasilkan oleh sel Th-17. Innate Lymphoid Cells $\mathrm{T} \gamma \delta$, iNKT, LTi-like juga memproduksi IL-17 and IL-2. ${ }^{15,16}$ Banyak penelitian yang menunjukkan bahwa $\gamma \delta T$ cells yang memproduksi IL-17 merupakan komponen yang sangat penting pada respon cepat pada awal terjadinya infeksi dalam upaya pertahanan tubuh terhadap pathogen asing. ${ }^{17,18}$ Sitokin IL-17 dan IL-22 memerankan peran proteksi pada pertahanan tubuh melawan berbagai pathogen asing dan melindungi barier mukosa dengan meningkatkan ekspresi antimicrobial peptide yang termasuk diantaranya beta defensin. ${ }^{19,20}$

$\beta$ defensin (BD) adalah antimicrobial peptides dengan ukuran kecil yang diekspresikan terutama oleh sel epitel mukosa. $\beta$ defensin diekspresikan terutama saat terjadi inflamasi, infeksi, dan proses perbaikan jaringan yang merupakan respon terhadap adanya antigen asing, dan sekresi sitokin ataupun metabolit pathogen. ${ }^{21,22} \beta$-Defensin memiliki kemampuan membunuh bakteri pathogen yang berusaha untuk menginvasi barrier inang. ${ }^{22,23}$ Selain itu $\beta$ defensin memiliki peran dalam menginduksi respon imun adaptif dengan rekruitmen monosit, sel dendritik, dan sel $\mathrm{T}$ menuju area inflamasi. ${ }^{24} \beta$-Defensin juga menginduksi ekspresi berbagai molekul kostimulator pada monosit dan sel dendritik melaluli 
interaksi dengan TLR 4. ${ }^{23}$ sehingga meingkatkan klirens patiogen asing. Kelebihan yang dimiliki oleh $\beta$-Defensin yang lain adalah kemampuannya dalam menginduksi sekaligus menginhibisi aktifasi sel imun, sehingga menjadikannya sebagai protein yang mampu memodulasi sistem imun inang. ${ }^{23,24}$

Pemberian molekul adhesi berupa sub unit pili $18 \mathrm{kDa}$ S. flexneri pada penelitian ini melalui oral. Hal ini berdasarkan pada pathogenesis $S$. flexneri yang menginfeksi inang melalui jalur rute feko-oral. Selain efektif, pemberian protein sub unit pili melalui oral memiliki keuntungan yang yaitu mudah pemberiannya, tidak melukai mencit, dan tidak perlu metode asepsis. ${ }^{25}$ Tujuan utama dari prosedur vaksinasi jenis apapun adalah untuk membentuk respon protektif dengan memori yang panjang dan kualitas respon imun yang memadai terhadap infeksi berikutnya.

Selain itu, kurangnya waktu pemberian perlakuan juga berpengaruh pada respon imun yang terjadi. Respon imun yang terbentuk hingga dapat menghasilkan sitokin fase respon imun adaptif melalui proses yang cukup panjang dan membutuhkan waktu yang lebih lama. Proses tersebut dimulai dengan antigen pada usus yang dipresentasikan pada sel T oleh APC (makrofag, sel dendritik, dan sel limfosit B). Pada folikel, antigen dipresentasikan pada sel B oleh sel dendritik folikular. Selama Patch of Peyer terpapar dengan antigen, sel limfosit yang naïve (sel T dan B) teraktivasi menjadi sel efektor. Setelah meninggalkan Patch of Peyer, sel limfosit aktif mengikuti aliran limfe menuju kelenjar getah bening menseterial dan berakhir pada ductus thoracicus kemudian masuk kedalam darah dan bersirkulasi keseluruh tubuh. Selanjutnya sel limfosit masuk kembali ke jaringan mukosa usus (homing) melalui pembuluh darah kecil yang terdapat pada dinding usus dan menyebabkan respon imun mukosa usus . ${ }^{26}$ Selain itu, pemberian imunisasi protein sub unit Omp S. flexneri $28 \mathrm{KDa}$ harus diberikan dengan secara kontinyu, karena pemeliharaan aktivitas protektif sel $\mathrm{T}$ helper bergantung pada adanya stimulasi antigen secara kontinyu. Keberadaan stimulasi kemokin dibutuhkan secara kontinyu untuk perekrutan dan retensi sel $\mathrm{T}$ di jaringan. ${ }^{14}$

Untuk data kadar $\beta$ defensin, dari hasil independent $T$ sample, kadar $\beta$ defensin antara kedua kelompok perlakuan, menunjukkan adanya perbedaan antara kelompok kontrol dan dan kelompok perlakuan yang dilakukan imunisasi sub unit pili $18 \mathrm{kDa}$ S. flexneri. Hal ini membuktikan bahwa kelompok yang diberi perlakuan imunisasi sub unit pili $18 \mathrm{kDa} S$. flexneri dapat meningkatkan kadar $\beta$ defensin, sedangkan kelompok kontrol tidak dapat meningkatkan kadar $\beta$ defensin. Hal ini menunjukkan bahwa pemberian imunisasi protein adhesi sub unit pili $S$. flexneri $18 \mathrm{kDa}$ saja mampu meningkatan kadar $\beta$ defensin.

\section{KESIMPULAN}

1. Pemberian protein adhesi sub unit pili $18 \mathrm{kDa} S$. flexneri selama 4 minggu meningkatkan secara bermakna kadar Antimicrobial peptide Beta defensins pada serum, mukosa usus, dan paru mencit.

2. Kadar Antimicrobial peptide Beta defensins paling tinggi didapatkan pada mukosa usus mencit. 


\section{UCAPAN TERIMAKASIH}

Peneliti mengucapkan terimakasih kepada Diktis Kemenag yang telah memberikan bantuan dana BOPTN 2018 pada penelitian ini.

\section{DAFTAR PUSTAKA}

1. UNICEF. 2013. Semakin banyak anak bertahan hidup melewati usia lima tahun. http://www.unicef.org/indonesia/id/media_23111.html

2. Direktorat Jenderal Pemberantasan Penyakit Menular dan Penyehatan Lingkungan Pemukiman (Ditjen PPM \& PLP). 2009. Tatalaksana Kasus Diare Bermasalah. Departemen Kesehatan RI; Badan Koordinasi Gastrointerologi Anak Indonesia

3. Herwana. 2010. Shigella-associated Diarrhea in Children in South Jakarta Indonesia. Southeast Asian J Trop Med Public Health. - USA : Southeast Asia J Trop Med Public Health. 2 : Vol. 41.p.418-25.

4. Sansonetti, P. J. 2004. War and peace at mucosal surfaces. Nat. Rev. Immunol. 4:953964.

5. Sperandio B. 2008. Virulent Shigella flexneri subverts the host innate immune response through manipulation of antimicrobial peptide gene expression. Exp. Med. 5 : Vol. 205.p.1121-1132.

6. Tortora G.J, Berdell R, Christine L. 2010. Microbiology an Introduction. Tenth edition. Benjamin Cummings

7. Chakrabarti M. 2010. A Simple Approach Towards The Development Of A Shigella Vaccine. Al Ameen J Med Sci. 4 : Vol. 3. p. 263-264.

8. Ehara, M. Ishibashi, Y. Ichinose, M. Iwanaga, S. Shimotori and Naito, T. 1987. Purification and Partial Characterization of Fimbriae of Fimbriae of Vibrio cholerae 01. Vaccine. 5(4): 283-8

9. Center For Disease Control and Prevention. 2006. General Recommendation on Immunization. Recommendation of the advisory Committee on Immunization Practice. MMWR. 55: $1-48$

10. Aagaard C, Hoang T, Dietrich J, cardona P, Izzo A, Dolganov G, et al. 2011. A multistage tuberculosis vaccine that confers efficient protection before and after exposure. Natural Med. 17:189-194.

11. Agger E, Rosennkrands I, Hansen J, Brahimi K, vandahl B, Aagaard C, et al. 2008. Cationic liposomes formulated with synthetic mycobacterial cordfactor (CAF01): a versatile adjuvant for vaccines with different immunological requirements. PLoS One 3:e3116. doi:10.1371/journal.pone.0003116.

12. Lindenstram T, Woodworth J, Dietrich J, Aagaard C, Andersen P, Agger EM. 2012. .Vaccine-Induced Th17 Cells Are Maintained Long-Term Postvaccination as a 
Distinct and Phenotypically Stable Memory Subset. Journal ASM.Volume 80(10) : 3533-3544

13. Rohrl J, Yang D, Oppenheim JJ, Hehlgans T. 2010. Human \{beta $\}$-Defensin 2 and 3 and Their Mouse Orthologs Induce Chemotaxis through Interaction with CCR2. $J$ Immunol. 2010;184:6688-6694.

14. Sotirakis P.K., Simonazzi E., Navarro P.J., and Rozières A. 2012. Differential capacity of human skin dendritic cells to polarize CD4+ T cells into IL-17, IL-21 and IL-22 producing cells. PLoS ONE 7:e45680. doi: 10.1371/journal.pone.0045680

15. Blaschitz C \& Raffatelu M. 2010. Th 17 cytokines and the gut mucosal barrier. J Clin Immunol. 30. 196-203

16. Steinbach, Sabine; Vordermeier, H Martin; Jones, Gareth J. 2016. CD4+ and [gamma][delta] T Cells are the main Producers of IL-22 and IL-17A in Lymphocytes from Mycobacterium bovis-infected Cattle. Nature Publishing Group. Scientific Reports 6.Doi:10.1038./srep29990.

17. Hamada S, Umemura M, Shiono T, Tanaka K, Yahagi A, Begum MD, et al. 2008. IL-17A produced by gammadelta $\mathrm{T}$ cells plays a critical role in innate immunity against Listeria monocytogenes infection in the liver. J Immunol. 181: 3456-3463.

18. Raifer, H., Mahiny, A. J., Bollig, N., Petermann, F., Hellhund, A., Kellner, K., et al. 2012. Unlike alphabeta T cells, gammadelta T cells, LTi cells and NKT cells do not require IRF4 for the production of IL-17A and IL-22. Eur. J. Immunol. 42, 31893201. doi: 10.1002/eji.20114215

19. Hasegawa M., Yada, S., Liu, M. Z., Kamada, N., Munoz-Planillo, R., Do, N., et al. 2014. Interleukin-22 regulates the complement system to promote resistance against pathobionts after pathogen-induced intestinal damage. Immunity 41, 620-632. doi: 10.1016/j.immuni.2014.09.010

20. Muñoz, M., Eidenschenk, C., Ota, N., Wong, K., Lohmann, U., Kühl, A. A., et al. 2015. Interleukin-22 induces interleukin-18 expression from epithelial cells during intestinal infection. Immunity 42, 321-331. doi: 10.1016/j.immuni.2015.01.011

21. Corrales G.L, Ortiz E, Delgado cJ, Santiago B, Corzo G. 2013. Bacterial expression and antibiotic activities of recombinant variants of human $\beta$-defensins on pathogenic bacteria and M. tuberculosis. Protein Expr Purif. 2013;89:3343.doi:10.1016/j.pep.2013.02.007.

22. Archer N.K, Adappa N.D, Palmer J.N, Cohen N.A, Harro J.M, Lee SK., Miller L.S, Shirtliff M.E. 2016. IL-17A and IL-17F are critical for antimicrobial peptide production and clearance of Staphylococcus aureus nasal colonization. Infection and immunity. Journal of American Society for microbiology . 16.doi:10.1128/IAI.0059616 
23. Zhu C, Tan H, Cheng T, Shen H, Shao J, Guo Y, Shi S and Zhang X. 2013. Human $\beta$-defensin 3 inhibits antibiotic-resistant Staphylococcus biofilm formation. J Surg Res. 183:204-213.

24. Jarczak J, Kościuczuk EM, Lisowski P, Strzałkowska N, Jóźwik A, Horbańczuk J, Krzyżewski J, Zwierzchowski L and Bagnicka E. 2013. Defensins: natural component of human innate immunity. Hum Immunol. 74:1069-1079.

25. Katz D.E, Coster T.S, Wolf M.K, Trespalacios FC, Cohen D, Robins G, Hartman AB, Venkatesan MM, Taylor DN, Hale TL. 2004. Two studies evaluating the safety and immunogenicity of a live, attenuated Shigella flexneri 2a vaccine (SC602) and excretion of vaccine organisms in North American volunteers. Infect Immun 72:923930. doi:.10.1128/IAI.72.2.923-930.2004

26. Bodera, P. \& Chcialowski, A. 2009. Immunomodulatory Effect of Probiotic Bacteria. Recent Patents. Inflammation \& Allergy Drug Discovery. 3, 58-64 